\title{
THE USE OF INTERNET AND SOCIAL MEDIA FOR DRUG INFORMATION SERVICES IN PHARMACIES IN YOGYAKARTA PROVINCE: A STUDY OF ASTHMA CARE
}

\author{
Fajar Ira Juwita, Aris Widayati*), Enade Perdana Istyastono \\ Faculty of Pharmacy, Universitas Sanata Dharma, Kampus III Paingan Maguwoharjo Depok \\ Sleman Yogyakarta, 55282, Indonesia
}

Received October 26, 2019; Accepted November 28, 2019

\begin{abstract}
Industrial revolution 4.0 is the process of digitizing the industry that leds health services in the era of application of Information and Communication Technology (ICT) called e-health. The application of ICT in Pharmacy is known as e-pharmacy. The role of pharmacists in Drug Information Services by utilizing ICTs has an effect on e-health literacy which ultimately supports the success of patient therapy. This is very important for patients with chronic diseases who are receiving treatment for a long time, one of which is asthma patients. Therefore, this study aims to explore pharmacist perceptions regarding the use of the internet and social media for drug information services, with a case study of services in asthma patients. This research is descriptive with a qualitative approach. Data is collected by interviews using an interview guide that has been validated in a professional judgment. Interviews were conducted with pharmacist participants who provided pharmacy services to asthma patients, who were selected purposively in March to July 2019. Data from interviews were transcribed verbatim, then a thematic analysis was performed. Ethical clearance has been obtained under number 945/ C.16/ FK/ 2019. The results of the study mention the use of the internet and social media indicate the potential capabilities of pharmacists in health services and also the challenges of transformation to the role of pharmacists in the epharmacy era. This study also mentions the urgency of establishing regulations regarding epharmacy that is driven by the violation from the internet and social media use. Improvement of ICT infrastructure in the pharmacy field as well as the pharmacist's contribution on the provision of drug information for chronic diseases, including asthma, are urgently required.
\end{abstract}

Keywords: asthma; drug information services; e-health, e-pharmacy; internet; social media.

\section{INTRODUCTION}

The use of Information and Communication Technology (ICT) has been growing up incredibly. This phenomenon is part of the era of industrial revolution 4.0 (Hermann n.d., Bigirimana and Chinembiri 2015, Rüßmann et al. 2015). The use of ICT in health services is known as e-health, which also has been developing extremely (Ruxwana $e t a l$. 2010(Board 2004)). E-health covers supportive, promotive, preventive, and curative, also rehabilitative activities (World Health Organization 2015, Lee and Lim 2017).
Pharmacist is one of health professionals who has been familiar with the use of ICT for the services, especially for purchase and storage of medicines (Webster and Spiro 2010, Westerling et al. 2011). The use of ICT in pharmaceutical areas is known as e-pharmacy (European commission 2012). Examples of e-pharmacy includes epurchasing, e- prescribing, and e-dispensing (Nanji et al. 2009, Webster and Spiro 2010, Malathi et al. 2018). The use of ICT in pharmaceutical services can help to improve patient's medication adherence through drug information services (Goundrey-Smith 2014). 
For example, a reminder tool based on internet use has been developed in Pennsylvania USA to improve medication adherence for asthma patients (Pool et al. 2017). In Canada, there has been a community of asthma patients who interact each other through a social media platform with a health professional as a guide (Letourneau et al. 2012).

Indonesia is one of the top five most populated countries in the world. As a consequence, a huge amount of internet users resides in Indonesia (Internet World Stats 2016, Kominfo 2017). In the health care context, especially pharmaceutical care services, the use of internet could help in improving health services to people. Patients with chronic disease are a group of population who requires a special service to improve their quality of life. Since they commonly receive more than three types of medicines for long duration of medication, the use of internet for drug information service could facilitate patient's medication adherence. Asthma is one of chronic diseases in Indonesia with a prevalence escalation, and therefore it requires more attention. The use of ICT on asthma care seems promising, as has been done in the USA and Canada mentioned earlier. Drug information service for asthma patients applying an internet platform is required to be developed. However, study on the use of ICT on asthma care in the Indonesia context is very rare. Therefore, this study aimed in exploring pharmacists' perceptions on the use of ICT platform to provide drug information service, with asthma pharmaceutical care as a model in this study.

\section{METHODS}

\section{Study design and variables}

This is an observational study with a qualitative approach (FHI 2005). The qualitative approach applied in this study aimed to explore in more details regarding the use of internet and social media for providing drug information to asthma patients from the perspectives of pharmacists who practice in pharmacies in Yogyakarta.

Exploration on the use of internet and social media to provide drug information for asthma patients from pharmacists' perspectives were focused on these variables: 1) capability of use; 2) advantages and disadvantages of use; 3) barriers and expectations of use.

\section{Data collection technique}

Data were gathered using interview technique. This technique provides opportunity for participants to give their thought regarding the topics questioned freely and responsively (Kallio et al. 2016). An interview guideline was formulated based on a theoretical framework named COM-B (Capacity, Opportunity, Motivation to perform a Behavior) (Eliasson et al. 2011). This theoretical framework was applied to assist in guiding questions to explore perceptions on the use of internet and social media to deliver drug information to asthma patients based on pharmacists' views. The interview guideline was assessed using a professional judgement approach. A pharmacist who is expert in using this theoretical framework and is familiar with pharmacist's standard of practice, especially in delivering drug information was asked to assess the guideline.

\section{Sampling technique and recruitment of the participants}

Participants of this study were pharmacists who met the inclusion criteria, which is those who practice in pharmacies in Yogyakarta and had served their asthma patients at least one month before. The participants were selected non-random purposively. The purposes in selecting the participants were: 1) selecting those who would provide detailed explanation on the use of internet and social media for drug information service, especially for their asthma patients; 2) selecting those to fulfil variations as much as possible, in term of gender, age, experience, and location of the pharmacies.

Recruitment of the participants was conducted followed these steps: 1) identified pharmacists who met the inclusion criteria and listed as potential participants; 2) contacted the potential participants and approached them to confirm their voluntary participation in this study; 3) made appointment for interview with those who agreed to participate in this study. 


\section{Data collection process}

Interviews were conducted during March to July 2019. A trained interviewer met a potential participant in a scheduled time. A brief information of this study were delivered to the potential participant. After that, the potential participant was asked to sign an inform consent to confirm her/his voluntary participation. Interviews were done face-toface for about 45 to 60 minutes per-participant. Interviews were audio-taped subject to participants' approval. The process of data collection was discontinued after data saturation was achieved. This mean that there is no new type of information given by at least the last three interviewees (Saunders et al. 2018).

\section{Data analysis}

Results of the interviews were transcribed verbatim and were analyzed thematically. The steps of thematic data analysis are as follows: 1 ) repetitive reading of the verbatim; 2) coding ideas found in the reading; 3) grouping the almost similar ideas with a new code; 3 ) extracting the grouped ideas into a theme and drawing the emerged themes into a theme's map. Since constructs of the COM-B theoretical framework informed the interview guideline, the theme's map were referred to those constructs.

\section{Ethical clearance and research permit}

Table 1. Participants' characteristics of the study of pharmacists' perception in using internet on social media to deliver drug information to asthma patients in Yogyakarta

\begin{tabular}{lc}
\hline \multicolumn{1}{c}{ Characteristics } & Number $(\mathrm{N}=15)$ \\
\hline Age & 7 \\
$<35$ years & 8 \\
$\geq 35$ years & 14 \\
\hline Gender & 1 \\
$\quad$ Male & 5 \\
Female & 10 \\
\hline Length of practice as a pharmacist & \\
$\quad<10$ year & 7 \\
$\geq 10$ year & 4 \\
Type of the pharmacy & 4 \\
Individual pharmacy & \\
Chain pharmacy & \\
Pharmacy at Primary Health Centre &
\end{tabular}


“.... soalnya kalau telepon gitu kan sudah tidak jamannya, mahal juga, kalau SMS [Short Message Service] juga tidak bisa memuat gambar, tapi kalau WA [WhatsApp] itu kan bisa lebih fleksibel apapun bisa dimasukkan kesitu...." (R13J)

Eight participants even stated that they have been communicating regularly with their asthma patients.

"Kalau kemarin dengan Bu P. A [nama pasien asma rutin] ini justru kita malah via Whatsapp.... Itu saya hubungi dan beliau juga sudah kasih nomornya ke saya, lalu saya hubungi via WA [Whatsapp]." (R6P)

All participants also mentioned that they can benefit from the use of social media to improve their knowledge by reading some specific information shared by other pharmacists from around the country, with no barriers of time and place.

“Terus mungkin juga bagusnya itu, ... soalnya media sosial membahas tentang kayak pertemuan-pertemuan ilmiah rutin. Tapi lewat medsos kan tidak terbatas ruang dan waktu ... lebih fleksibe lah istilahnya, daripada harus ada pertemuan itu, harus ke tempat itu, butuh waktu." (R2NJ)

To support advertisements of pharmacy and pharmacist's activities

Some of the participants put a particular information in their social media status or profile picture, such as in Instagram, Facebook, Whatsapp. They used the specific feature in the social media as a tool to spread their activities related to their service provisions.

".....Whatsapp itu kan apabila kita minta nomer kontaknya (pasien) terus sengaja kita upload story tentang PIO [Pelayanan Informasi Obat] itu akan sangat mudah menyebar dan dibaca oleh yang punya kontak kita, kalau ada keluarga atau ada teman atau ada sanak saudara yang membutuhkan mereka bisa kembali men-share kepada yang bersangkutan...." (R15P)

Intrenet and social media is also seen by all the participants as an opportunity to introduce pharmacists' role to society.

"Yang maksud satu arah itu contohnya itu kayak informasi yang diberikan itu arah dari kita (apoteker) itu bisa sih di media sosial lewat media sosial untuk memperkenalkan apoteker juga bisa” (R12NJ)

To support searching of sources of drug informartion

All the participants agreed that internet helped them in searching information easily and quickly.

"Kalau keuntungannya [penggunaan internet] sih kita bisa tau apa-apa ya .... Ditanya sama pasien gitu kan kita bisa langsung cari [informasi], langsung nети... (R5J)

To support other pharmaceutical service provisions

Most of the participants mentioned that their pharmacy has been supported by wireless internet connection. They convinced that such facility can help to provide services in their pharmacy.

"Terus pelayanan informasi obat untuk mencari obat baru misalnya ada permintaan resep tapi di sini gak ada obatnya ya kita searching dengan bantuan wifi atau internet, bisa dicari lewat komputer atau pakai handphone. Ya banyak dimudahkan lah dengan adanya wifi kita untuk searching informasi." (R11NJ)

Some participants said that they did partnership with a particular provider of internet-based marketing platform to improve their sales; for example, the HaloDoc.

"Kalau jualan online, kami kerjasama sama HaloDoc. Untuk meningkatkan omset sangat bermanfaat." (R1NJ)

The second theme: Challenges of pharmacist's roles transformation in the era of e-pharmacy

As a reliable drug informer

Some participants said that mostly patients prefer to search drug information through internet, especially for self medication instead of having consultation with pharmacists. Participants see this fact as a potential disadvantage of the use of internet as information accessed through the internet is not always valid and reliable. 
"Kadang orang tidak mau bertanya kepada tenaga kesehatan, mereka lebih memilih untuk cari dulu di internet, nah ketika sumber yang dicari itu istilahnya tidak punya basic secara ilmu kesehatan kadang kan berbeda cara pandangnya." (R1NJ)

"Jadi kalau ruginya itu terkait apa yang mereka buka sendiri di internetnya. Kadang ada informasi yang belum valid nah mereka kadang cuma baca aja dan mereka bilang mau ini [obat tertentu].” (R8J)

The fake and misleading health information potentially leads to jeopardize to the society.

"Kerugiannya adalah kalau saya melihat secara umum atau untuk kasus ini, ya kadang terdapat berita yang simpang siur atau hoax gitu ya. Yang malah bingung. kita [apoteker] itu sudah betul-betul on the track apa belum, jadi kita [apoteker] bingung sendiri, ini bener nggak sih?" (R2NJ)

As an authority person of online pharmacy

Participants who work at a chain pharmacy mentioned that there is a special group of pharmacists in their corporation, who has a specific duty regarding digital marketing. This team is specifically responsible to the management of online pharmacy.

“.....memang itu apoteker semua mbak, jadi tugas kami ini ada pengenalan produk (iklan) kemudian ada produk diskon, lalu job karir ya macam-macam itu apoteker semua yang mengerjakan. Digital marketing ini istilahnya, kami ada transformasi mbak, transformasi untuk dibuat job-job apa yang harus dilakukan salah satunya digital marketing, tugasnya ya itu tadi [salah satunya] untuk membuat PIO [Pelayanan Informasi Obat]." (R13J)

As an educator to improve society's health literacy

Participants mentioned that pharmacist should have capability and capacity to select a qualified information retrieved from the websites or social media. They have to assure that information obtained through the internet must be qualified, valid, and reliable to be shared to the society.
"Kalau kekurangan nya sih itu tadi kalau kita [apoteker] tidak bisa menyaring informasi, kita [apoteker] jadi memberikan informasi yang salah. Makanya itu menjadi tepat dan cepat kalau kita [apoteker] bisa memilih sumber informasi yang benar dari internet gitu." (R12NJ)

The third theme: urgency of regulation regarding e-pharmacy (online pharmacy)

Most participants stated that there are a lot of online shops that sell medicines, not only the over-the-counter medicines but also the prescription only medicines which must be obtained using prescription. Even, the online shops are run without supervision from an authorized person, i.e.: pharmacist. Further, participants stated that regulation regarding online pharmacy is urgent.

"Bahwa itu enggak tepat kalau seperti itu itu loh, kalau mau ada online sih oke, tetapi betulbetul harus di handle oleh orang yang memang berwenang di situ dan yang berkompeten di situ itu. Jangan hanya penjual lepas gitu kan, tidak ada kejelasan apapun dan sebagainya. Regulasinya harus betul-betul ketat dan tegas. Tapi kan lebih bagus kalau ini bisa berlaku secara nasional ada peraturan perundangundangan lah atau dari Kementerian Kesehatan seperti itu kan?" (R2NJ)

Further, participants expressed their concern regarding the missuse of the internet for selling medicines in a website.

"Terus juga kalau menurut saya negatifnya adalah karena di situ [toko online] ini tidak menutup kemungkinan juga untuk pemanfaatan media sosial dan internet ini juga untuk untuk kasus-kasus kejahatan tertentu juga, atau mungkin bisa juga pemanfaatan penipuan dan sebagainya, ini yang sangat tidak diharapkan." (R2NJ)

\section{The fourth theme: improving the ICT facilities}

Participants who work in Primary Health Centre (PHC) said that there are barriers in using internet and social media to support their pharmaceutical care service. The main barrier they mentioned are the unstable internet 
connection that causes delay or suboptimal of the service.

"Tapi kadang kendalanya ya mungkin ada kendala jaringan juga. Sehingga itu yang dirasa kita sebagai kerugiannya, misalkan pas ada kendala-kendala... Jadi bisa tidak cepat juga, kayak gitu, kalau ketika ada kendala seperti itu." (R6P)

They also convinced that there are still many PHCs in remote rural areas that have not been reached by the internet, in other words internet network infrastructure is still limited.

"Terkait dengan akses informasi artinya di Puskesmas sendiri di setiap desa belum tentu menggunakan internet yang memiliki akses yang cepat, hanya orang-orang tertentu yang bisa mengakses internet itu masih sangat terbatas sehingga untuk infrastruktur internet masih sangat terbatas." (R14P)

\section{The fifth theme: pharmacist's contribution on people's e-health literacy regarding chronic diseases.}

Participants in this study stated that pharmacists can contribute on the improvement of people's literacy regarding health and the use of internet and social media to search qualified health information. For example, information about medication adherence.

"Bisa untuk lebih meningkatkan tingkat pemahaman dari dari masyarakat ya tentang kesehatan, tentang penyakit, tentang pengobatannya. Kemudian ya terus terutama juga tentang bisa memberikan masukan juga tentang kepatuhan. Kepatuhan dalam hal melakukan terapi itu harapannya sih seperti itu dan bisa diakses secara luas dan secara mudah, secara murah gitu ya." (R2NJ)

Some participants who work at retail pharmacies expected to use internet and social media to support their professional role. They expected that the use of internet and social media would help them to improve patients' knowledge regarding medicines and medication, to improve patient's medication adherence, including asthma medication.

"Ayo bikin ini, untuk diposting, misalkan seperti itu. Pada prinsipnya tetap ingin menggunakan internet sebagai media untuk kita bisa terus memberikan informasi obat kepada masyarakat, kepada pasien sehingga bisa ikut meningkatkan kepatuhan penggunaan obat dan juga meningkatkan pengetahuan tentang obat gitu ya, terhadap asma juga." (R5P)

Participants stated that pharmacists must increase their contribution on delivering drug information using an internet and social media. They expected that through the use of internet and social media to communicate with patients and people and improve patient's quality of life, the role of pharmacist will be appreciated by society.

"Saya berharap dengan adanya pasien tahu informasi obat di internet, ya walaupun masih dalam kendali kita ya, artinya tidak seluruhnya. Apoteker dalam membuat ini itu semuanya disampaikan. Berharap pasien ini quality of life nya tetap bagus ya." (R13J)

"Semoga pasien asma bisa mengontrol kondisi kesehatannya karena kalau asma kan tidak bisa disembuhkan, hanya bisa dikontrol. Meningkatkan kualitas hidup aja sih... dan ketika dia mendapatkan informasi yang sesuai, dia akan bisa menjaga, istilahnya menjaga menjauhkan diri dari alergen atau dapat tahu cara penggunaan inhaler maupun alat yang digunakan untuk kesehatannya dengan baik." (R1NJ)

Participants were aware that information regarding chronic diseases, including asthma, is easily searched via internet. However, they underlined that further detailed consultation must be handled by pharmacists as a health professional who are expert in medicines.

"Misalnya mencari kata Asma ya pakai yang mudah dipahami masyarakat terus kemudian bisa disitu penanggungjawabnya boleh sih kalau misalnya itu jadi ada kontak, mungkin beberapa udah ada ya misalnya kayak contact person atau registrasi email jadi kalo kita mau berhubungan dengan orang yang memposting informasi itu." (R9P)

This qualitative study underlines five themes from pharmacists' perspectives regarding the use of internet and social media to deliver drug information to asthma patients as a model. The five themes are: 1) Pharmacist's capability in using internet and social media to 
support the services; 2) Challenges of pharmacist's roles transformation in the era of e-pharmacy; 3) Urgency of regulation regarding e-pharmacy (online pharmacy); 4) improving the ICT facilities; 5) Pharmacist's contribution on people's e-health literacy regarding chronic diseases.

The first theme emerged through this study is pharmacist's capability in using internet and social media to support pharmaceutical care practice. Pharmacist's capability in using internet and social media is a strength, especially in the era of "internet of things". On the other side, there is a big need from society to receive reliable information regarding medicines, especially through online communication (Leonita and Jalinus 2018). For examples: the use of video uploaded in a website to educate asthma patients regarding the use of inhaler and other asthma medical devices (Benetoli et al. 2017) and the use of internet-based integrated information system in hospital and community pharmacy to improve health services, including pharmaceutical care services (Lalitaphanit 2016). Internet and social media also provide a huge opportunity for pharmacists to improve and share their knowledge with their colleagues, even with other health professionals without any significant boundaries (Webster and Spiro 2010, Leonita and Jalinus 2018). Online communication using internet can minimize barriers of time and location (Ruxwana et al. 2010). Therefore, pharmacists should equip themselves with adequate knowledge and skill regarding the use of internet and social media to deliver drug information to their patients as well as to have professional communication with other health professionals (Eliasson et al. 2011).

The second theme is the need of transformation of pharmacist's role from "offline pharmacist" to "online pharmacist". In the era of "internet of things" there is a need and challenge for pharmacists to transform their roles, especially regarding the use of ICT to improve pharmaceutical care services (Bigirimana and Chinembiri 2015). The need of transformation is triggered by the increase of internet used by society to search information regarding medication and medicines. Social media and website become the most popular sources of health information accessed by people. The online and user friendly sources of information become a popular choice when people got difficulty in meeting pharmacists face-to-face (Crilly et al. 2019). There is also a tendency of people to share their experiences regarding their own health problems. Information shared by lay people based on their own experience tend to be trusted by society (Bhaskaran et al. 2017). However, there is a crucial problem when people are not able to differentiate between qualified information and false information (Prasanti 2018). Therefore, pharmacist must take a role in helping people to get a valid and reliable information they search via internet. In this case, pharmacists must play their role as an educator to improve people's health literacy using internet-based platforms (MacLure and Stewart 2018). Further, challenge of the pharmacist transformation role is how to develop pharmaceutical care service using internet-based platforms (Webster and Spiro 2010, MacLure and Stewart 2018). For example, in Scotland pharmacists has been supported by government to transform in managing e-prescribing and e-Health Record in collaboration with other health professional in hospital (MacLure and Stewart 2018).

The third theme is urgency of regulation regarding e-pharmacy. Authorized online pharmacy has been growing up very fast. On the other hand, selling medicines on the websites illegally is also common (Ebner 2012). Obtaining medicines sold in illegal websites will jeopardize consumers, especially regarding the risk of selecting and using the purchased medicines inappropriately (Chaturvedi et al. 2015). Therefore, there is an urgent need to regulate online medicines trading via websites.

The fourth theme is the prerequisite to improve ICT facilities. The ICT will revolutionize the way to deliver pharmaceutical care services the patients (Ruxwana et al. 2010). However, ICT infrastructures in some extends is still inadequate (Benetoli et al. 2017). In the Indonesia context, fast connection remains a problem of the ICT facilities. 
The fifth theme is pharmacist's contribution regarding people's e-health literacy especially in managing chronic diseases. Pharmacists must take their role as an educator to improve people's health literacy. Pharmacist must also design and develop new ways to engage with society members to improve people knowledge and awareness regarding the use of medicines safely (Benetoli et al. 2017). The use of internet creates a huge opportunity for pharmacists to get involve in improving the society's literacy regarding health (MacLure and Stewart 2018).

This study is not without its limitation. The nature of interview method in gathering data would likely to provide a big chance for participants to answer the question openly and freely. This could lead to a response bias. In this study, although questions were queried using a guideline with emphasizing on asthma care, yet participants tended to answer using a perspective of chronic diseases as general. The inclusion criteria of recruitment of participants, which was pharmacists who had experience in delivering pharmaceutical care service to asthma patients within a month before the interview, was an anticipating approach to minimize such a response bias, however. Furthermore, as asthma care in this study only becomes a model, the participants' responses could possibly describe chronic diseases as general.

\section{CONCLUSION}

Using the asthma care as a model this study concludes that the use of internet and social media to support pharmaceutical care services is promising. There are challenges and opportunities for pharmacists to take an advanced role in the era of "internet of things" to improve patient's quality of life. Further research is needed to develop new and appropriate internet-based platforms that can be used to support the pharmaceutical care services.

\section{ACKNOWLEDGEMENT}

The authors would like to thank you the participants involved in this study voluntary and to the thesis examiner panel of the Master of Pharmacy Study Program at Faculty of Pharmacy Sanata Dharma University for the valuable advises. The authors declare that this study was funded by Kemenristek DIKTI through "Hibah Penelitian Tesis Magister tahun 2019” (No. 029/Penel./LPPM_USD/IV/2019) with Aris Widayati, M.Si., Apt., PhD as the Principal Investigator.

\section{REFERENCES}

Benetoli, A., Chen, T.F., Schaefer, M., Chaar, B., and Aslani, P., 2017. Do pharmacists use social media for patient care? International Journal of Clinical Pharmacy, 39, 364-372.

Bhaskaran, N., Kumar, M., Janodia, M.D., 2017. Use of Social Media for Seeking Health Related Information - An Exploratory Study, 9 (2), 267-271.

Bigirimana, S., Chinembiri, M., 2015. Towards E-Pharmacy: The Future Information and Communication Technologies Needs for Community Pharmacies in Harare, Zimbabwe. International Journal of Economics, Commerce and Management, III (4), 1-26.

Board, E., 2004. eHealth: Report by the Secretariat (Executive Board EB115/39 115th Session, Provisional agenda item 4.13), (1), 1-6.

Chaturvedi, A., Kumar, A., Noida, G., 2015. Online pharmacy: an e-strategy for medication, (April 2011).

Crilly, P., Hassanali, W., Khanna, G., Matharu, K., Patel, D., Patel, D., Rahman, F., Kayyali, R., 2019. Research in Social and Administrative Pharmacy Community pharmacist perceptions of their role and the use of social media and mobile health applications as tools in public health. Research in Social and Administrative Pharmacy, 15 (1), 23-30.

Ebner, N., 2012. Electronic copy available at: http://ssrn.com/abstract=2170559. Signal, 27 (2), 10-14.

Eliasson, L., Barber, N., Weinman, J., 2011. Applying COM-B to medication adherence work tended to focus on the role and its effects on patient, 7-17.

European commission, T.H.E., 2012. EU 
eHealth Action Plan 2012 to 2020.

FHI, I.F.H., 2005. Qualitative Research Methods: A Data Collector's Field Guide.

Goundrey-Smith, S., 2014. Examining the role of new technology in pharmacy: now and in the future [online]. Available from: https://www.pharmaceuticaljournal.com/examining-the-role-of-newtechnology-in-pharmacy-now-and-in-thefuture/11134174.article.

Hermann, M., n.d. Design Principles for Industrie 4.0 Scenarios: A Literature Review.

Internet World Stats, 2016. Internet World Stats [online]. Internet World Stats. Available from: http://www.internetworldstats.com/ [Accessed 8 Nov 2018].

Kallio, H., Pietilä, A.M., Johnson, M., Kangasniemi, M., 2016. Systematic methodological review: developing a framework for a qualitative semistructured interview guide. Journal of Advanced Nursing, 72 (12), 2954-2965.

Kominfo, 2017. Jumlah Pengguna Internet 2017 Meningkat, Kominfo Terus Lakukan Percepatan Pembangunan Broadband [online]. Available from: https://kominfo.go.id/content/detail/1264 0/siaran-pers-no-53hmkominfo022018tentang-jumlah-pengguna-internet2017meningkat--kominfo-terus-lakukanpercepatan-pembangunanbroadband/0/siaran_pers/ [Accessed 23 Nov 2018].

Lalitaphanit, T., 2016. Factors affecting community pharmacy customers' decision to use personal health records via smartphone. Thai Journal of Pharmaceutical Sciences, 42.

Lee, J.-Y., Lim, J.-Y., 2017. The Prospect of the Fourth Industrial Revolution and Home Healthcare in Super-Aged Society. Annals of Geriatric Medicine and Research, 21 (3), 95-100.

Leonita, E., Jalinus, N., 2018. Peran Media Sosial dalam Upaya Promosi Kesehatan : Tinjauan Literatur, 18 (2), 25-34.

Letourneau, N., Stewart, M., Masuda, J.R., Anderson, S., Cicutto, L., McGhan, S., Watt, S., 2012. Impact of Online Support for Youth With Asthma and Allergies: Pilot Study. Journal of Pediatric Nursing, 27 (1), 65-73.

MacLure, K., Stewart, D., 2018. A qualitative case study of ehealth and digital literacy experiences of pharmacy staff. Research in Social and Administrative Pharmacy, 14 (6), 555-563.

Malathi, S., Priadarsini, M., Dharshana, M., Agathiya, T., 2018. Big Data and CPS ( Cyber Physical System ) used in Pharmacy to Alert on Expiration of Medicine, 8 (4), 16946-16948.

Nanji, K.C., Cina, J., Patel, N., Churchill, W., Gandhi, T.K., Poon, E.G., 2009. Overcoming Barriers to the Implementation of a Pharmacy Bar Code Scanning System for Medication Dispensing: A Case Study. Journal of the American Medical Informatics Association, 16 (5), 645-650.

Pool, A.C., Kraschnewski, J.L., Poger, J.M., Smyth, J., Stuckey, H.L., Craig, T.J., Lehman, E.B., Yang, C., Sciamanna, C.N., 2017. Impact of online patient reminders to improve asthma care: A randomized controlled trial. PLoS ONE, 12 (2), 1-17.

Prasanti, D., 2018. Literasi Informasi Kesehatan sebagai Upaya Pencegahan Informasi Hoax dalam Penggunaan Obat Tradisional di Era Digital Health Information of Literation as Prevention Processes of Hoax Information in the Use of Traditional Medicine in Digital Era, 3 (1), 45-52.

Rüßmann, M., Lorenz, M., Gerbert, P., Waldner, M., Justus, J., Engel, P., Harnisch, M., 2015. Industry 4.0: The Future of Productivity and Growth in Manufacturing Industries. Business and Information Systems Engineering, 6 (4), 239-242.

Ruxwana, N.L., Herselman, M.E., Conradie, D.P., 2010. ICT applications as e-health solutions in rural healthcare in the Eastern Cape Province of South Africa. The HIM journal, 39 (1), 17-26.

Saunders, B., Sim, J., Kingstone, T., Baker, S., Waterfield, J., Bartlam, B., Burroughs, H., Jinks, C., 2018. Saturation in qualitative 
research: exploring its conceptualization and operationalization. Quality and Quantity, 52 (4), 1893-1907.

Webster, L., Spiro, R.F., 2010. Health information technology: A new world for pharmacy. Journal of the American Pharmacists Association, 50 (2), e20-e34.

Westerling, A.M., Haikala, V., Airaksinen, M., 2011. The role of information technology in the development of community pharmacy services: Visions and strategic views of international experts. Research in Social and Administrative Pharmacy, 7 (4), 430-437.

World Health Organization, 2015. Regional Strategy for Strengthening eHealth in the South-Asia Region 2014-2020. 